\title{
ROTATED GRAZING IN BRACHIARIA BRIZANTHA CV. MARANDU TO IMPROVE MILK PRODUCTION
}

\section{ORIGINAL ARTICLE}

SOARES, Marcio Groto ${ }^{1}$, CAMARGO, Simone Cristina², FRASSETTO, Matheus Orlandin ${ }^{3}$, ABREU, Hélio Mar de ${ }^{4}$

SOARES, Marcio Groto. Et al. Rotated grazing in Brachiaria brizantha cv. marandu to improve milk production. Revista Científica Multidisciplinar Núcleo do Conhecimento. Year. 06, Ed. 09, Vol. 07, pp. 104-118. September 2021. ISSN: 24480959, Access Link: https://www.nucleodoconhecimento.com.br/veterinariaen/rotated-grazing, DOI: 10.32749/nucleodoconhecimento.com.br/veterinariaen/rotated-grazing

\section{ABSTRACT}

In dairy properties, in order for there to be an increase in profit, it is necessary to increase the efficiency of production factors, especially nutrition, which impacts the fixed cost. Increasingly, a balance is sought between the supply of feed and pasture. The rotational grazing method has been adopted by several producers, as it has good productivity in a smaller area. However, the pastures used in this type of grazing, despite their excellent quality, have higher nutritional requirements. The objective of this work was to carry out an economic analysis of the cost of milk production, through the implantation of rotational grazing, and exchange of native pasture for Brachiaria brizantha cv. marandu, on a family farm. This work was prepared in the city of Foz do Iguaçu. An area of $6300 \mathrm{~m}^{2}$ was used, divided into 28 paddocks of $225 \mathrm{~m}^{2}$ using an electric fence. The total cost of production was

\footnotetext{
${ }^{1}$ Graduation.

${ }^{2}$ Doctorate degree.

${ }^{3}$ Professor.

${ }^{4}$ Graduation.
}

RC: 99519

Available in: https://www.nucleodoconhecimento.com.br/veterinaria-en/rotated- 
$\mathrm{R} \$ 6,047.40$, with a positive margin of $\mathrm{R} \$ 5.143 .61$ per year. According to the results obtained in the economic analyses, it is concluded that the implantation of rotational grazing and the exchange of native pasture for Brachiaria brizantha cv. Marandu is a viable management, since the income generated by the sale of milk was sufficient to cover the total costs of production.

Keywords: Cost, Milk, Fodder, Picket, Handling.

\section{INTRODUCTION}

Brazil ranks fourth in the world ranking of milk production. In 2018, the Southern region accounted for $34 \%$ of the country's total production (ANUÁRIO LEITE, 2019). The state of Paraná alone this year produced an average of 4.37 billion liters of milk, of which western Paraná was responsible for 19\% (IBGE, 2018).

Dairy cattle in the state of Paraná is a typical activity of family farming, representing approximately $85.1 \%$ of the state's producers (SEAB, 2018). Most of these producers use pasture as the main source of food for animals. The average area occupied with pastures in the state is 16.6 hectares (IPARDES, 2009).

Although Brazil stands out in milk production, its productivity is around 1,689 L/cow/year, which is lower than in the United States, China, Russia, Argentina, the European Union and New Zealand, which produce more than $3 \mathrm{~L} / \mathrm{cow} / \mathrm{year}$. One of the factors responsible for low milk yield is the use of poorly productive grasses of low nutritional quality, together with inadequate management of both animals and pastures (GONÇALVES et al., 2003).

One way to intensify animal production in grazing systems is to the adoption of improved fodder, more adapted to the climate, with higher production potential and better quality (JANK, 2017). Among the various fodder existing in Brazil, stands out the hybrid variety of brachiaria brizantha $c v$. marandu grass, for presenting a good

RC: 99519

Available in: https://www.nucleodoconhecimento.com.br/veterinaria-en/rotatedgrazing 
nutritional value and high biomass production, adapting well to soils of medium and good fertility, being tolerant to soil acidity (FONSECA et al., 2010).

The correct management of pasture should be another point to be observed in the properties of milk cattle. One of the grazing that has been shown to be viable is the rotational, where there is subdivision of the pasture into three or more pickets. This type of grazing has several advantages, such as: greater grazing uniformity, greater use of forages, higher stocking rate, and longer longevity of weeds that form clumps (FUKUMOTO et al., 2010).

Different studies have shown good results for dairy cattle, with the implantation of rotational grazing in Brachiaria brizantha cv. marandu grass (GONÇALVES, 2003); (DEMSKI, 2013), (MOURA, 2017). According to (ANDRADE, 2008), this type of pasture does not tolerate continuous grazing.

With the correct choice of forage, proper management and better use of the property area, it seeks to generate savings to the producer, since it will reduce the cost of production. According to (GERON, 2012), the cost of production is the sum of all the amounts spent on insumand operations and services used in the production process of a certain activity. With the study of costs, it is possible to verify how the resources used in a production process are being remunerated and how is the profitability of the activity (GERON et al., 2014).

Thus, the objective of this work was to perform the economic analysis of the cost of milk production, through the implementation of rotational grazing, and exchange of native pasture for pasture of Brachiaria brizantha $\mathrm{cv}$. marandu, on a family farming estate.

\section{MATERIAL AND METHODS}

The experiment was carried out in a dairy property located in the city of Foz do Iguaçu - PR, Latitude: -25.5469, Longitude: $-54.588225^{\circ} 32^{\prime} 49^{\prime \prime}$ South, $54^{\circ} 35^{\prime} 18^{\prime \prime}$

RC: 99519

Available in: https://www.nucleodoconhecimento.com.br/veterinaria-en/rotated- 
West. This property is composed of an area of 5.0 hectares, in this area was developed a traditional dairy cattle to the region, where the animals had access to the entire grazing area, composed of native grass of low productivity, there was no availability of mineral salt, only common salt in the trough and being only available a supplementation at the time of milking of $10 \mathrm{~kg}$ of by lactating animals and access to water was from a stream that passes through the property.

The property has six dairy cattle, composed of four adult cows, two lactating cows and two dried cows, plus two heifers. These animals were managed throughout the pasture area throughout the year and the lactating animals received $10 \mathrm{~kg}$ of industrialized feed per day.

Work began with a visit to the property for a diagnosis. Measurements of the pasture area were performed using GPS (Figure 1) and also soil collection (Figure 2). The results of soil analysis are (Table 1 ).

Figure 1 - Satellite photo of the experimental area, with the demarcation of the pasture area:

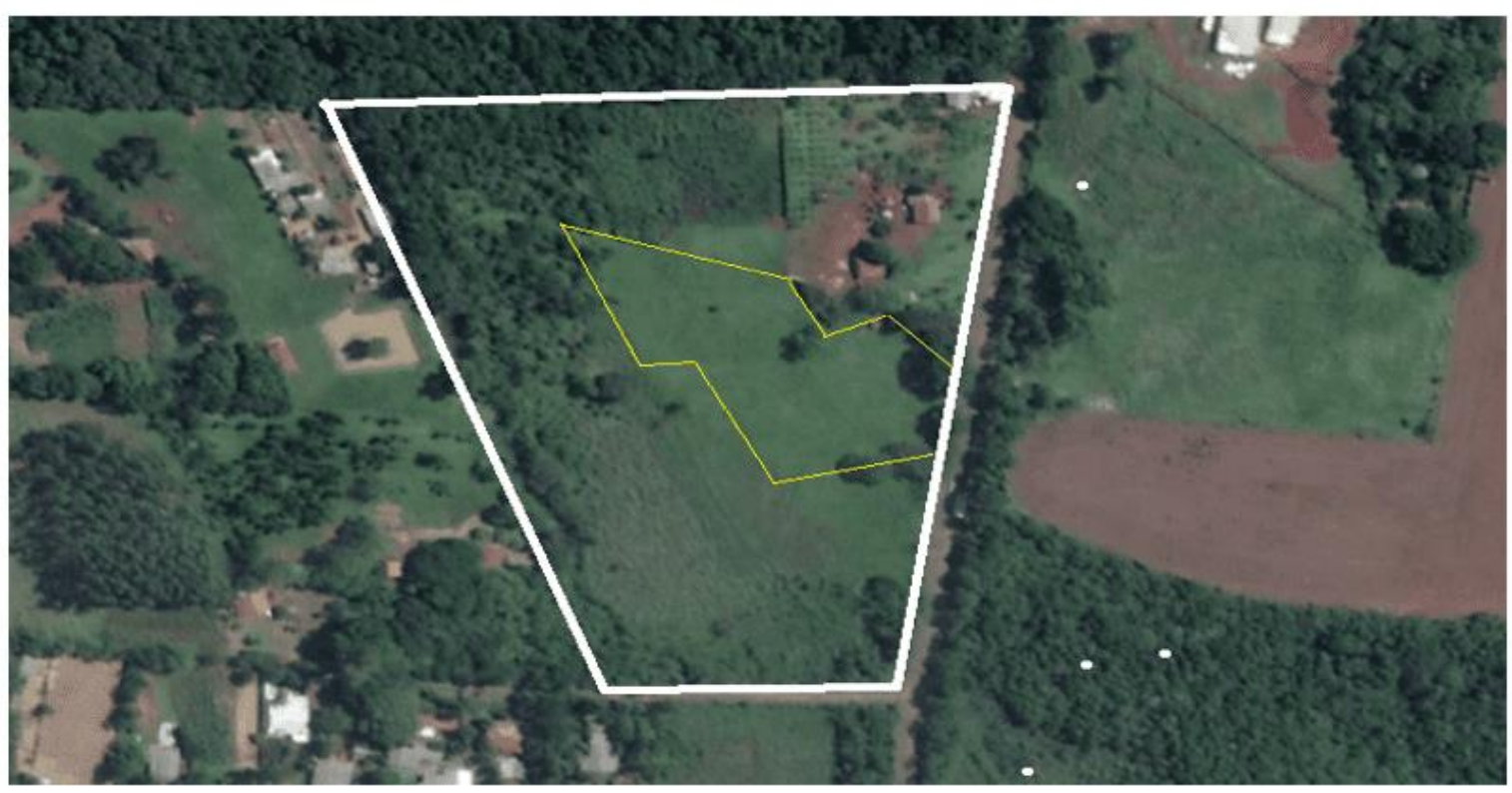

Source: Google Earth.

RC: 99519

Available in: https://www.nucleodoconhecimento.com.br/veterinaria-en/rotatedgrazing 
Figure 2 - Soil sample collection:

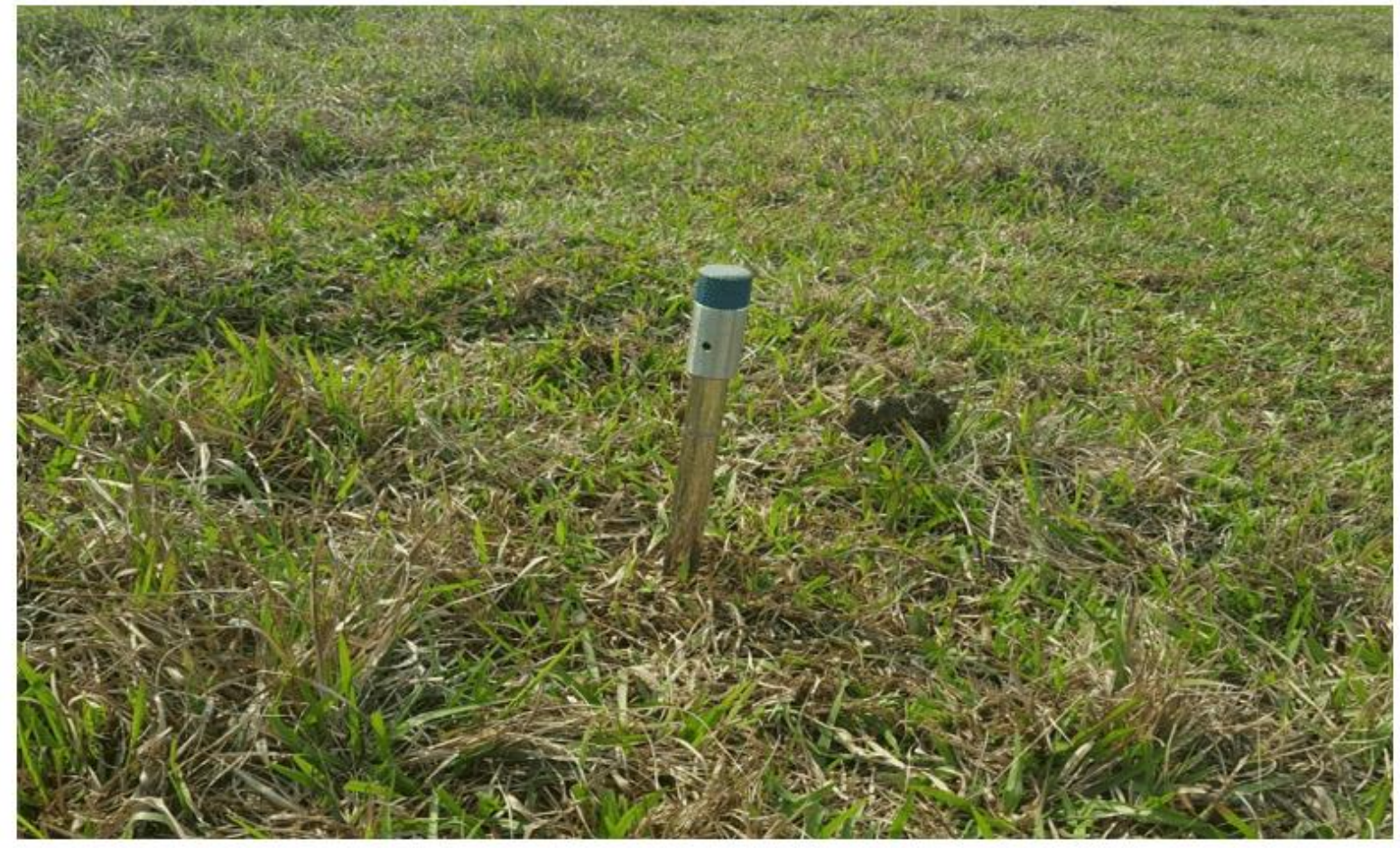

Source: Personal Archive.

Table 1 - Results of soil analysis of the experimental area:

\begin{tabular}{|c|c|c|c|c|c|c|c|c|c|c|c|c|c|c|}
\hline $\mathrm{pH}$ & & & $\mathrm{K}$ & $\mathrm{Ca}$ & $\mathrm{Mg}$ & $\mathrm{Al}$ & $\mathrm{H}+\mathrm{Al}$ & CTC & SB & V & $\mathrm{m}$ & $\mathrm{Ca}$ & $\mathrm{Mg}$ & $\mathrm{K}$ \\
\hline \multirow[t]{2}{*}{$\mathrm{CaCl} 2$} & M.O & $\mathrm{P}$ (res) & & & & & & & & & & & & \\
\hline & $\mathrm{g} / \mathrm{Kg}$ & $\mathrm{mg} / \mathrm{dm} 3$ & \multicolumn{5}{|c|}{$\mathrm{mmol} / \mathrm{dm} 3$} & $\%$ & & & \multicolumn{4}{|c|}{$\%$ СТC } \\
\hline 5,2 & 38 & 14 & 3 & 21 & 5 & 2,7 & 29 & 58 & 29 & 50 & 8 & 36 & 9 & 5 \\
\hline
\end{tabular}

Source: FZEA/USP.

After receiving the soil analysis, soil correction calculations were made, where the V\% was $58 \%$. To correct the soil $\mathrm{pH}, 800 \mathrm{~kg} \mathrm{ha}^{-1}$ of dolomitic limestone with $86 \%$ PRNT was necessary. To correct the phosphorus, it was necessary to add $250 \mathrm{~kg} \mathrm{ha}$ ${ }^{1}$ of simple superphosphate fertilizer. For the production fertilization, $250 \mathrm{~kg} \mathrm{ha}^{-1}$ of agricultural urea was used (FRASSETO, 2015).

RC: 99519

Available in: https://www.nucleodoconhecimento.com.br/veterinaria-en/rotatedgrazing 
To start the soil preparation, the application of limestone was applied throughout the experimental area, and soon after, a heavy grid was used, with a depth of $40 \mathrm{~cm}$, which served to incorporate limestone into the soil, break surface compactions and give conditions to the growth of the new forage species.

For a dimensioning of the area necessary for grazing, the cows were weighed using a weighing tape with $95 \%$ accuracy, totaling $1950 \mathrm{~kg}$ or $4.5 \mathrm{AU}$. Because dairy cattle are used, it was determined that the animals would have access to a new paddock at the end of a day of grazing. Therefore, data from (FRASSETO 2015) were used, in which an UA (450 kg live weight) needs at least $50 \mathrm{~m}^{2}$ per day of grazing area. Knowing that there were $4.5 \mathrm{AU}$, the area of each paddock was $225 \mathrm{~m}^{2}$. A total of 28 paddocks were built, using 0.63 hectares. During the construction of the pickets, it was necessary to add three corridors, $2 \mathrm{~m}$ wide.

For the splitting of the pickets were used 50 mourões, 72 rebar of $10 \mathrm{~mm}, 32$ rebar of $12 \mathrm{~mm}, 500 \mathrm{~m}$ of tri galvanized wire for about the total perimeter of the area and $2500 \mathrm{~m}$ of electroplastic wire for the internal division of the pickets, 150 insulators brown type, 22 hook insulators and 114 insulators type rebar. Wire wire with a height of $80 \mathrm{~cm}$ was used in relation to the ground and each $10 \mathrm{~m}$ a $1.5 \mathrm{~m}$ rebar with insulator was implanted to maintain the height in relation to the ground, electroplastic wire was also used to divide the pickets and reduce the formation costs. To electrify the wire, a Sentinel electrifier model 30,000 was used, with a minimum of 5000 volts.

RC: 99519

Available in: https://www.nucleodoconhecimento.com.br/veterinaria-en/rotated- 
Figure 3 - Sketch of the picket division:

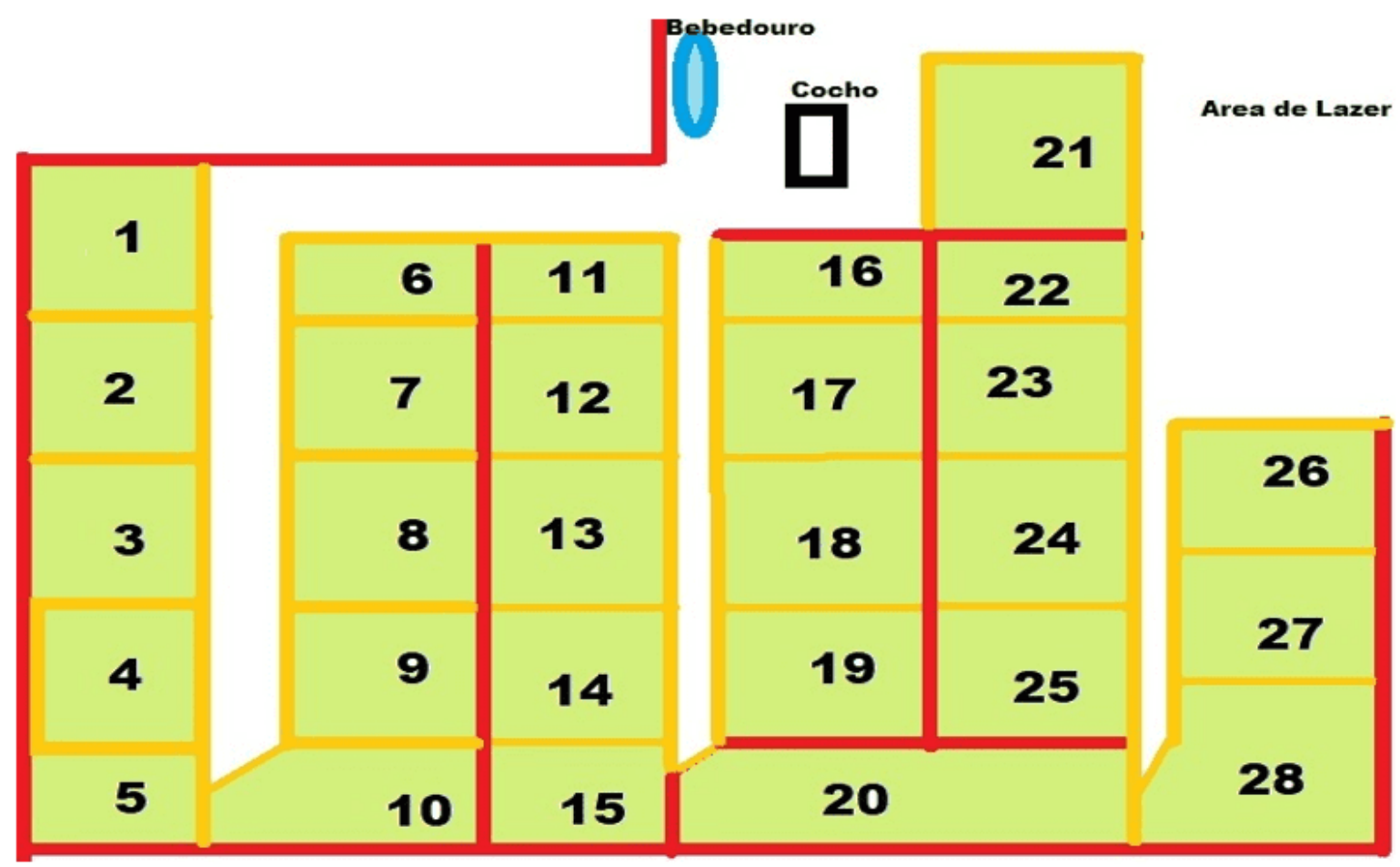

Source: Personal Archive.

The forage chosen was Brachiaria Brizantha $\mathrm{cv}$. marandu, the management of this forage starts when the plant reaches $30 \mathrm{~cm}$ at the entrance and $15 \mathrm{~cm}$ at the exit Andrade (2008); Fonseca (2010). Forage planting and planting fertilization began on $11 / 15 / 2019$, with the broadcast planting method and incorporation of seeds and super-simple phosphate fertilizer afterwards. The seeds were incrusted, using $15 \mathrm{~kg}$ ha $^{-1}$.

The first production fertilization was carried out 60 days after planting, applying 125 $\mathrm{kg} \mathrm{ha}^{-1}$ of agricultural urea with $45 \%$ nitrogen. The first grazing began on $02 / 03 / 2020$, 77 days after planting. The second fertilization of production being applied $125 \mathrm{Kg} \mathrm{ha}$ 1 of agricultural urea was carried out in the first grazing cycle being 28 days after the beginning of the first grazing.

RC: 99519

Available in: https://www.nucleodoconhecimento.com.br/veterinaria-en/rotatedgrazing 
For the rest of the animals was added a water drinker with approximately $100 \mathrm{~L}$ of water, addition of mineral salt suitable for dairy cattle and the trees of the property themselves served as shading.

To perform the economic analysis and evaluation of the cost of milk production, we identified the agents involved, as well as the values that represent the effects of the implementation of the project on these agents, also considering the closing of one year.

To evaluate the cost of implementation of the project, we considered the costs of investing in soil preparation and planting of the grass, as well as investments for infrastructure and equipment in the formation of pickets.

To evaluate the cost of production, we used the structure of the operational cost of production, proposed by Matsunaga (1976). In which, the effective operational cost (COE), corresponds to the expenditure of money by the producer, with purchase of feed, expenses with the maintenance of pasture and medicines, for one year.

For the total cost of production (CTP), depreciation was added to (COE). The annual depreciation of the pasture was calculated by the sum of the supplies necessary for the construction of the electric fence divided over a period of ten years. Depreciation of $10 \%$ per year (CANZIANI et al., 2000).

To calculate revenue, net revenue was considered, which is the amount gained in milk delivery per year minus total production costs (MARTIN, 1997).

\section{RESULTS AND DISCUSSION}

Within agricultural production, it is necessary to have a planning by the producer, so that there is growth and development of the activity. Therefore, the first step in the study of the feasibility of a project is to survey expenses for its implementation. The

RC: 99519

Available in: https://www.nucleodoconhecimento.com.br/veterinaria-en/rotated- 
costs for the implementation of this project, from the preparation of the soil for the planting of the pasture, to the formation of the pickets were $R \$ 3,023.70$.

Before performing the implantation of grass $B$. brizantha $\mathrm{cv}$. marandu, it was necessary to prepare the soil. Investments related to soil tillage are described in (Table 2).

Table 2 - Investment costs in soil preparation and planting:

\begin{tabular}{|l|l|l|l|}
\hline Description & Unit & Quantity & Value (R\$) \\
\hline $\begin{array}{l}\text { Soil Analysis } \\
\text { Dolomite limestone }\end{array}$ & Uni & 1 & 33,00 \\
\hline $\begin{array}{l}\text { 86\%) } \\
\text { Superphosphate (00.19.00) }\end{array}$ & $\mathrm{Kg}$ & 800 & 156,00 \\
\hline Tractor aration time & $\mathrm{Kg}$ & 250 & 287,46 \\
\hline Encrusted seed & $\mathrm{Kg}$ & 2 & 400,00 \\
\hline Agricultural Urea & $\mathrm{Kg}$ & 250 & 287,01 \\
\hline Herbicide Glyphosate & $\mathrm{Ml}$ & 500 & 35,00 \\
\hline Oil 2T & $\mathrm{Ml}$ & 250 & 20,00 \\
\hline Fuel - Gasoline & $\mathrm{L}$ & 5 & 20,00 \\
\hline Total & & & $\mathbf{1 . 6 3 8 , 4 7}$ \\
\hline
\end{tabular}

Source: Project Data.

The costs of soil tillage and planting represented $54.20 \%$ of the total costs for pasture implantation. Corrective practices and soil fertilization are only part of the requirements necessary for the success of the pasture production system (PEREIRA et al., 2018).

It is important for the producer to invest and perform a good soil preparation and a correct implementation of the pasture, always seeking balance in the soil-plantanimal system (PEREIRA et al., 2018). These managements will influence the

RC: 99519

Available in: https://www.nucleodoconhecimento.com.br/veterinaria-en/rotatedgrazing 
increase of animal production, as well as in the reduction of feed expenses for animal feed.

In the search for a correct management of the pasture, it was subdivided into pickets. Investments for infrastructure and equipment in the formation of pickets are represented in (Table 3).

Table 3 - Cost table for the formation of pickets, with the electric fence:

\begin{tabular}{|c|c|c|c|}
\hline Description & Unit & Quantity & Value $(\mathrm{R} \$)$ \\
\hline Eletrix wire & $\mathrm{m}$ & 500 & 184,00 \\
\hline $\begin{array}{l}\text { Electroplastic wire } 500 \\
\text { m }\end{array}$ & $\mathrm{m}$ & 5 & 104,82 \\
\hline Brown insulator & Uni & 150 & 176,98 \\
\hline Rebar insulator & Uni & 114 & 131,65 \\
\hline $\begin{array}{l}\text { Short hook type } \\
\text { insulator }\end{array}$ & Uni & 20 & 24,00 \\
\hline $\begin{array}{l}\text { Long hook-type } \\
\text { insulator }\end{array}$ & One & 2 & 4,60 \\
\hline Switch switch & One & 3 & 36,00 \\
\hline Rebar (3/8") 1.5 m & One & 72 & 284,30 \\
\hline Rebar (1/2") 1.5 m & One & 2 & 186,18 \\
\hline PVC tube 20 mm 6 m & One & 1 & 12,80 \\
\hline Digital voltmeter & One & 1 & 139,90 \\
\hline Electrifier & One & 1 & 100,00 \\
\hline Total & & & $1.385,23$ \\
\hline
\end{tabular}

Source: Project Data.

The costs of infrastructure and equipment for the formation of pickets represent $45.80 \%$ of the total costs of the implementation of the pasture. The rational

RC: 99519

Available in: https://www.nucleodoconhecimento.com.br/veterinaria-en/rotatedgrazing 
management of forage has widely demonstrated the benefits of dividing pastures, where there is a greater uniformity of grazing, greater utilization of forages, higher stocking rate, and greater longevity of weeds that form clump (FUKUMOTO, 2010), which is the case of $B$. brizantha cv. marandu. The use of the electric fence, in its different forms in picketling, is a necessary tool to implement at low cost the subdivisions that rotational grazing requires (EMBRAPA, 1999).

The assets that make up the enterprise are subject to constant devaluations, mainly due to wear and tear, and aging. (Table 4) has the depreciation data of the electric fence.

Table 4 - Depreciation of materials and equipment:

\begin{tabular}{|c|c|c|c|}
\hline Description & Total amount $\mathrm{R} \$$ & Shelf life (years) & Annual value \\
\hline $\begin{array}{ll}\text { Electric } & \text { fence } \\
\text { construction } & \end{array}$ & $1.385,25$ & 10 & 138,52 \\
\hline
\end{tabular}

Source: Project Data.

Table 5 - Investment payment:

\begin{tabular}{|l|l|l|l|}
\hline description & Total amount $\mathrm{R} \$$ & Payment time (years) & Annual value \\
\hline $\begin{array}{l}\text { Deployment } \\
\text { cost }\end{array}$ & $3,023.70$ & $\mathbf{1 0}$ & 302.37 \\
\hline
\end{tabular}

Source: Project Data.

To have greater annual control over business management, investments for deployment was divided into 10 years. $4.20 \%$ of the annual revenue from the sale of milk, described in (Table 5).

To calculate the monetary intake, in the form of money in one year, it was considered the amount paid to the producer per liter of milk, sold daily and direct from the form

RC: 99519

Available in: https://www.nucleodoconhecimento.com.br/veterinaria-en/rotatedgrazing 
producer for one year. To calculate the amount of annual milk was considered a daily milking in the morning with a total of 10 liters/day (Table 6).

Table 6 - Revenue from the sale of annual milk:

\begin{tabular}{|l|l|}
\hline Variables & Total value \\
\hline Price per liter $(\mathrm{R} \$)$ & 2,00 \\
\hline $\begin{array}{l}\text { Total liters of milk produced } \\
(\mathrm{L})\end{array}$ & $3.600,00$ \\
\hline Final revenue $(\mathrm{R} \$)$ & $\mathbf{7 . 2 0 0 , 0 0}$ \\
\hline
\end{tabular}

Source: Project Data.

Each year the producer will have to make an expenditure of money, which is considered an Effective Operational Cost (COE). The costs of feed, expenses with the maintenance of pasture and medications were taken into account (Table 7).

Table 7 - Effective Operating Cost - COE, per year:

\begin{tabular}{|l|l|l|l|l|}
\hline Description & Unit & Quant & Unit value R\$ & Total amount R\$ \\
\hline Ration & $\mathrm{Kg}$ & 720 & 1,32 & 950,04 \\
\hline Agricultural urea & $\mathrm{Kg}$ & 250 & 1,60 & 400,00 \\
\hline Electrical energy & $\mathrm{R} \$$ & 12 & 0,60 & 216,00 \\
\hline $\begin{array}{l}\text { Brucellosis vaccine } \\
\text { Rabies vaccine }\end{array}$ & Dose & 6 & 1,62 & 9,72 \\
\hline Dectomax 50 mL & Dose & 6 & 1,48 & 8,88 \\
\hline $\begin{array}{l}\text { Foot-and-mouth } \\
\text { vaccine }\end{array}$ & Uni. & 1 & 21,90 & 21,90 \\
\hline Total & Dose & 6 & 1,50 & 9,00 \\
\hline
\end{tabular}

Source: Project Data.

RC: 99519

Available in: https://www.nucleodoconhecimento.com.br/veterinaria-en/rotatedgrazing 
It is observed in this work that the largest expenditure on production is on feed. According to (MARTINEZ, 2009), spending on nutrition represents on average $67 \%$ of milk production costs in Brazil. Thus, strategies are sought to reduce the use of diets and other supplements. Improving pasture and managing it is an alternative that helps milk production be economically viable. For this reason, rotational grazing has been increasingly indicated (MARION et al., 2010).

Rosestolato (2015), when analyzing the economic viability of milk production of two distinct properties regarding the technological production system, observed that the (COE) on the property in which the cows were kept in a continuous grazing system and supplemented with concentrated feed and mineral salt was higher than that maintained in a rotational grazing system and supplemented with chopped sugarcane, concentrated feed and mineral salt.

In the property evaluated in this study, $10 \mathrm{~kg}$ of industrialized feed was given per lactating animal and after the implementation of the project there was a decrease of 9 $\mathrm{kg}$ starting to offer only $1 \mathrm{~kg}$ of feed to the animals, thus decreasing the (COE), as observed by Rosestolato (2015). However, supplementation to animals even with the change in grazing system is important, since it helps to supply in animals the nutrients that are lacking in the composition of the fodder. The cost of the feed represented $44.70 \%$ of all production costs.

Considering the depreciation and effective operating cost (COE) values, the total cost of production was obtained in one year (Table 8).

Table 8 - Total Cost of Production - CTP (Annual Basis):

\begin{tabular}{|l|l|}
\hline Description & Total amount R\$ \\
\hline Depreciation & 138,52 \\
\hline COE Costs & $1.615,50$ \\
\hline Investment & 302.37 \\
\hline
\end{tabular}

RC: 99519

Available in: https://www.nucleodoconhecimento.com.br/veterinaria-en/rotated- 
payment

Total

2.056,39

Source: Project Data.

In countries with low milk prices, producers are able to reduce the cost of production by increasing the participation of pasture in the diet of dairy cows. In this study, the total cost of production represented $28.55 \%$ of annual income.

To calculate revenue, net revenue was considered, which is the value gained in milk delivery per year minus total production costs (Table 9).

Table 9 - Revenue (Annual Basis):

\begin{tabular}{|l|l|}
\hline Description & Total amount R\$ \\
\hline Revenue & $7.200,00$ \\
\hline $\begin{array}{l}\text { Total Production Cost (CTP annual } \\
\text { basis) }\end{array}$ & $2.056,39$ \\
\hline Balance & $\mathbf{5 . 1 4 3 , 6 1}$ \\
\hline
\end{tabular}

Source: Project Data.

According to Oliveira (2007), knowledge of the implications of the effective operational cost (COE), in the short term, is fundamental in the management of the business, and the gross margin needs to be positive, if negative, the interruption of production is recommended.

The financial analysis of the implementation of this project proved to be feasible (Table 9). In view of the analyses made from the data obtained, it was observed that the investment in the rotational grazing technique in dairy cattle presents an economically viable return on invested capital and that the same positive influence on production making this activity more competitive in the sector. Thus this technique

RC: 99519

Available in: https://www.nucleodoconhecimento.com.br/veterinaria-en/rotatedgrazing 
allows the potential expression for milk production and the increase in the profitability of producers, which would make the dairy activity profitable, even in times of fall in the price of milk.

\section{FINAL CONSIDERATIONS}

According to the results obtained in the economic analyses, it is concluded that the implementation of rotational grazing and the exchange of native pasture by Brachiaria brizantha cv. marandu, is a viable management, since the revenues generated by the sale of milk were sufficient to cover the total costs of production.

This semi-intensive production system is recommended to the local reality, because it is an alternative of technological innovation, capable of reducing expenses with the purchase of feed, and providing a good animal performance, from the change of grazing management and grass insertion of better nutritional value and higher mass production.

\section{REFERENCES}

ANDRADE, Carlos Mauricio Soares de. Pastejo Rotacionado: Tecnologia para Aumentar a Produtividade de Leite e a Longevidade das Pastagens. EMBRAPA - Acre, dez. 2008.

ANUÁRIO LEITE 2019. Sua excelência, o consumidor: novos produtos e novas estratégias da cadeia do leite para ganhar competitividade e conquistar os clientes finais. Brasília, DF: Texto Comunicação Corporativa, 2019. Disponível em: <https://www.infoteca.cnptia.embrapa.br/infoteca/handle/doc/1109959>. Acesso em: 25 mar. 2020.

DEMSKI, Joana Baptista. Desempenho e comportamento de vacas lactantes em pastagens de cultivares de braquiárias. Dissertação apresentada ao Programa de

RC: 99519

Available in: https://www.nucleodoconhecimento.com.br/veterinaria-en/rotated- 
Pós-graduação do Instituto de Zootecnia, APTA/SAA. Nova Odessa - SP, 2013. $80 \mathrm{p}$.

FONSECA, Delermando Miranda da; MARTUSCELLO, Janaina Azevedo. Plantas forrageiras. Viçosa, 537p. 2010.

FUKUMOTO, Nelson Massaru; DAMASCENO, Júlio Cesar; DERESZ, Fermino, MARTINS, Carlos Eugênio; CÓSER, Antônio Carlos; SANTOS, Geraldo Tadeu dos. Produção e composição do leite, consumo de matéria seca e taxa de lotação em pastagens de gramíneas tropicais manejadas sob lotação rotacionada. Revista Brasileira de Zootecnia, v. 39, n.7, p. 1548-1557, 2010.

GERON, Luiz Juliano Valério; MEXIA, Alexandre Agostinho; GARCIA Jocilaine; SILVA Marciano Moreira da; ZEOULA, Lúcia Maria. Suplementação concentrada para cordeiros terminados a pasto sobre custo de produção no período da seca. Semina: Ciências Agrárias, Londrina, v. 33, p. 797-808, 2012.

GERON, Luiz Juliano Valério; MOURA, Daiane Caroline; RODRIGUES, Deivison Novaes; PAULA, Edson Júnior Heitor; TRAUTMANN-MACHADO, Raquel Joana; GARCIA, Jocilaine; SCHUMANN, Alline Mariá; SILVA; Dilma Alves. Viabilidade econômica de tourinhos terminados em confinamento alimentados com diferentes teores de caroço de algodão em dietas elaboradas com coprodutos agroindustriais. Semina: Ciências Agrárias, Londrina, v.35, p. 2673-2684, 2014.

GONÇALVES, Carlos Alberto; CAMARÃO, Ari Pinheiro; DUTRA, Saturnino; AZEVEDO, Guilherme Pantoja Calandrini de; MENDONÇA, Denise Castro; SOBRINHO, Carlos de Melo Junior. Produção de leite em pastejo rotacionado intensivo de "Brachiaria brizantha" cv. Marandu sob dois níveis de suplementação concentrado. In: Reunião anual da sociedade brasileira de zootecnia, 40., 2003, Santa Maria. Anais... Santa Maria: Sociedade Brasileira de Zootecnia, 2003.

RC: 99519

Available in: https://www.nucleodoconhecimento.com.br/veterinaria-en/rotated- 
IBGE -Instituto Brasileiro de Geografia e Estatística. [2018]. Pesquisa da pecuária nacional disponível em: <https://sidra.ibge.gov.br/Tabela/74>. Acessado em: 25 mar. 2020.

IPARDES: Instituto Paranaense de Desenvolvimento Econômico e Social. Caracterização sócio econômica da atividade leiteira no Paraná: Sumário executivo. Curitiba: IPARDES, 2009. 29 p.

JANK, Liana; ANDRADE, Carlos Mauricio Soares de; BARBOSA, Rodrigo Amorim; MACEDO, Manuel Claudio Motta; VALERIO, Jose Raul; VERZIGNASSI, Jaqueline Rosemeire; ZIMMER, Ademir Hugo; FERNANDES, Celso Dornelas; SANTOS, Mateus Figueiredo; RESENDE, Rosangela Maria Simeão. O capim-BRS Quênia (Panicum maximum Jacq.) diversification and intensification of pastures. Available in: <https: ainfo.cnptia.embrapa.br/digital/bitstream/item/165106/1/capimbrs-quenia-panicum-maximum-jacq.pdf="'>.</https:> Access on: 25 Mar. 2020.

MARION, Jose Carlos; SEGATTI, Sonia. Contabilidade da Pecuária. 9 ed. São Paulo: Atlas, 2010.

MARTIN, Nelson Batista; SERRA, Renata; OLIVEIRA, Marli Dias Mascarenhas; ÂNGELO, José Alberto; OKAWA, Hiroshige. Sistema "CUSTAGRI": sistema integrado de custos agropecuários. São Paulo: IEA/SAA, 1997. p. 1-75.

MARTINEZ, Junior Cesar. Produção de leite a pasto: manejo do pastejo é fundamental para manter a produção. 2009. Disponível em: $<$ http://www.milkpoint.com.br/radartecnico/nutricao/producao-deleite-a-pasto-manejodo-pastejo-e-fundamental-para-manter-aproducao-51710n.aspx>. Acesso em: 27 mai. 2020.

MATSUNAGA, Minoru; BEMELMANS, Paul Frans; TOLEDO, Paulo Edgard Nascimento de; DULLEY, Richard Domingues; HIROSHIGE, Okawa; PEDROSO, Iby

RC: 99519

Available in: https://www.nucleodoconhecimento.com.br/veterinaria-en/rotatedgrazing 
Arvatti. Metodologia de custo utilizada pelo IEA. Agricultura em São Paulo, v. 23, n. 1, p.123-39, 1976.

OLIVEIRA, Jefferson Soares de. Análise de eficiência e alocação de recursos na produção leiteira do estado do Rio de Janeiro. In: congresso da sociedade brasileira de economia, administração e sociologia rural, 45., 2007. Londrina. Conhecimentos para a agricultura do futuro: Anais... Brasília, DF: SOBER; Londrina: IAPAR: Universidade Estadual de Londrina, 2007.

PEREIRA, Lilian Elgalise Techio. et al. Recomendações para correção e adubação de pastagens tropicais. Pirassununga: Faculdade de Zootecnia e Engenharia de Alimentos da USP, 2018. 56p.

ROSESTOLATO, Lucas Luiz Rocha. et al. Viabilidade econômica comparativa de sistemas tecnológicos da pecuária leiteira no município de llha Solteira/SP. Congresso de extensão universitária da UNESP, 8., p. 1-6, 2015. Disponível em: <http://hdl.handle.net/11449/142491>. Acesso em: 28 mai. de 2020.

SEAB - Secretaria de Estado da Agricultura e do Abastecimento. Bovinocultura de leite: leite - $\quad$ produção $2016 / 17 . \quad$ Disponível em:<http://www.agricultura.pr.gov.br/arquivos/File/deral/Prognosticos/2018/leite_201 7_18.pdf>. Acesso em: 25 mar. de 2020.

Posted: July, 2021

Approved: September, 2021.

RC: 99519

Available in: https://www.nucleodoconhecimento.com.br/veterinaria-en/rotated- 